\title{
Epidemiological Characteristics of Hepatitis A in Some Regions of Kazakhstan with Different Degrees of the Severity of Ecological Disaster
}

\author{
Maria N. Omarova, $\mathrm{PhD}, \mathrm{ScD}$; Lyazat Zh. Orakbay, $\mathrm{PhD}, \mathrm{ScD} *$; \\ Idelbay Kh. Shuratov, PhD, ScD; Aizhan B. Dzhumagalieva PhD; \\ Gul'sairam M. Akdauletova; Saltanat O. Aliaskarova, PhD \\ Scientific Centre of Hygiene and Epidemiology named after Hamza Zhumatov \\ Almaty, Kazakhstan
}

\begin{abstract}
The results of a retrospective epidemiological analysis of the hepatitis A incidence among children in the studied territories showed no connection between the incidence rate and the ecological status of the territory. the strategic vaccination of children in areas of high endemicity is the most effective way to control HAV, or possibly to eliminate it. (Int J Biomed. 2016;6(3):225-227.).
\end{abstract}

Key Words: hepatitis A virus • incidence rate $\bullet$ cumulative indices $\bullet$ ecological disaster • vaccination.

\section{Introduction}

Hepatitis A(HA) is the most common form of acute viral hepatitis worldwide. The incidence rate is strongly related to socioeconomic indicators and access to safe drinking water. The hepatitis A virus (HAV) endemicity level for a population is defined by the results of age-seroprevalence surveys; a systematic review on the global prevalence of HAV infection was recently published by WHO. ${ }^{[1]}$ Areas of the world can be characterized as having high, intermediate, low, and very low endemicity for HA. Areas of high endemicity include most of Africa, Asia and Central and South America. In areas of high endemicity, the prevalence of anti-HAV IgG reaches $90 \%$ in adults, and most children have been infected by 10 years of age. ${ }^{[2]}$ In most middle-income regions in Asia, Latin America, Eastern Europe, and the Middle East, surveys of anti-HAV antibody in the population show a mix of intermediate $(\geq 50 \%$ are immune by age 15 years) and low ( $\geq 50 \%$ are immune by age 30 years) prevalence. ${ }^{[3]}$ Safe water supply, food safety, improved sanitation, hand washing and the hepatitis A vaccine are the most effective ways to combat the disease. ${ }^{[3-5]}$

"Corresponding author: Lyazat Orakbay, PhD, ScD. Scientific Centre of Hygiene and Epidemiology named after Hamza Zhumatov. Almaty, Kazakhstan.E-mail: ncgigieny@mail.ru
HA is still an important problem for Kazakhstan, despite the marked decline in the HA incidence of 12.2 times among children. It should be noted that the decrease in morbidity in different areas ranges from 5.3 times to its complete absence. $\mathrm{HA}$ is more frequently registered in the Kyzylorda region and South-Kazakhstan region, where the annual incidence among children under 14 years is 3 and 2.5 times higher than in the whole country. ${ }^{[6,7]}$

Kyzylorda region is a larger zone of the Kazakhstan part of the Aral Sea region, which was declared by government decree ${ }^{[8]}$ in 1990 as a zone of ecological disaster due to a sharp reduction in the water area of the sea. This area covers mainly the territory of Kyzylorda oblast and extends over part of the territory of neighboring South Kazakhstan oblast.

According to the severity of this ecologically unfavorable situation, the area of ecological disaster in the Aral Sea area is divided into three zones: 1) ecological catastrophe, 2) ecological crisis, and 3) ecological pre-crisis state.

Within the zone of ecological catastrophe are the Aral and Kazaly regions of Kyzylorda oblast and Shalharsky region of Aktobe oblast. The zone of ecological crisis encompasses Karmakchinsky, Zhalagash, Shieli, Syr Darya and Zhanakorgan regions, Kyzylorda city, and Baikonur, including the surrounding villages. Within a zone in an ecological pre-crisis state are Irgiz region in Aktobe oblast, 
Aris city and Turkestan in South Kazakhstan oblast, and Ulytau region in Karaganda oblast. ${ }^{[8]}$

Among epidemiologists and practitioners, it is believed that the relatively high incidence in South Kazakhstan and Kyzylorda oblasts is associated with the current environmental situation. This study is devoted to analysis of the HA incidence in the areas located in the zones with different degrees of severity of the environmental disaster.

\section{Materials and Methods}

For the retrospective epidemiological analysis, we used the data of the official registration of the Departments of Sanitation and Epidemiological Surveillance of the republic, regions and oblasts for the HA incidence in children for 20052014.

\section{Results and Discussion}

The generalized average annual epidemiological parameters for HA in the study areas, belonging to three different zones of ecological disaster, are given in Table 1. As can be seen, in Aralsk, Kazalinsk and Arys, relating to the zone of ecological catastrophe, the average annual incidence rates for children under 14 years of age amounted to 185.9, 86.3 and 334.7, respectively. In Karmakchi, Zhalagash and Shieli, relating to zone of ecological crisis, these indices were 101.8, 418.1 and 151.6, respectively.
In areas, relating to the area of an ecological pre-crisis state (villages Irgiz and Ulytau), these indices amounted to 11.3 and 77.9 respectively. In the control and environmentally safe village of Atasu, this index was $36.3 \%{ }_{0000}$. These data suggest that in the studied territories, there is no direct connection between the HA incidence in children and the severity of the environmental disaster.

In all studied regions of Kyzylorda oblast and Aris city of South Kazakhstan oblast, the highest incidence rates were observed among children between 3 and 6 years of age(from 158.8 to 2642.2); the relatively high rates were observed among children of 7 to 10 years of age. The proportion of children among HA patients in these territories ranged from $78.3 \%$ to $87 \%$. The identified epidemiological features of HA are most common for the naturally flowing HA epidemic process. ${ }^{[9]}$

We have previously shown that the effective vaccination program for HA prevention among children leads to noticeable changes in the epidemiological characteristics of HA. In particular, there is a decrease in the proportion of children in the structure of the annual incidence in population, a reduction of morbidity among young children with transference into the teenage group and young people group (15-19 years of age), the elimination or significant decrease in amplitude of cyclic recurrence of epidemic process. ${ }^{[10,11]}$

In the villages of Shalhar and Irgiz, as well as in Aktobe oblast as a whole, the incidence rate among children reached $11.3-14.2$, and the proportion of children, $28.1 \%$ to $30.3 \%$.

Table 1.

The epidemiological parameters of hepatitis $A$ in areas with different degrees of the severity of ecological disaster

\begin{tabular}{|c|c|c|c|c|c|c|c|c|c|c|c|}
\hline \multirow{3}{*}{ Oblast } & \multirow{3}{*}{$\begin{array}{l}\text { Zones of ecological } \\
\text { disaster }\end{array}$} & \multirow{3}{*}{ Region } & \multicolumn{9}{|c|}{ The average annual incidence rate for 10 years $\left(\%{ }_{0000}\right)$} \\
\hline & & & \multirow{2}{*}{$\begin{array}{c}\text { Children } \\
\text { under } 14 \\
\text { years }\end{array}$} & \multirow{2}{*}{$\begin{array}{c}\text { Proportion } \\
\text { of children } \\
(\%)\end{array}$} & \multicolumn{4}{|c|}{ Age groups, $\mathrm{y}$} & \multicolumn{3}{|c|}{ Socio-professional groups } \\
\hline & & & & & $1-2$ & $3-6$ & $7-10$ & $11-14$ & organized & unorganized & d schoolkids \\
\hline \multirow{5}{*}{ Kyzylorda oblast } & ecological crisis & Oblast & 247.1 & 73.2 & 193.3 & 343.4 & 250.0 & 120.2 & 191.8 & 154.6 & 137.9 \\
\hline & \multirow{2}{*}{ ecological catastrophe } & Aralsk & 185.9 & 84.1 & 167.2 & 251.5 & 226.5 & 99.7 & 283.4 & 165.8 & 149.8 \\
\hline & & Kazalinsk & 86.3 & 87.0 & 72.5 & 189.5 & 174.7 & 81.3 & 149.9 & 130.1 & 119.3 \\
\hline & \multirow[t]{2}{*}{ ecological crisis } & Zhalagash & 418.1 & 82.1 & 182.1 & 254.3 & 192.5 & 117.9 & 154.9 & 247.4 & 371.9 \\
\hline & & Shieli & 151.6 & 84.5 & 133.7 & 181.4 & 152.1 & 84.2 & 71.5 & 257.2 & 191.7 \\
\hline \multirow{2}{*}{ Aktobe oblast } & - & Oblast & 13.3 & 29.1 & 6.7 & 10.4 & 16.6 & 16.8 & 8.3 & 8.7 & 19.9 \\
\hline & ecological catastrophe & Shalhar & 14.2 & 30.3 & 8.5 & 9.2 & 12.1 & 14.5 & 9.1 & 11.7 & 15.2 \\
\hline \multirow{3}{*}{ Karaganda oblast } & - & Oblast & 54.2 & 52.3 & 43.1 & 211.3 & 205.1 & 186.9 & 28.3 & 49.5 & 85.7 \\
\hline & \begin{tabular}{ll|}
$\begin{array}{l}\text { ecological pre-crisis } \\
\text { state }\end{array}$ \\
\end{tabular} & Ulytau & 77.9 & 60.8 & 22.3 & 45.3 & 145.6 & 161.0 & 61.1 & 21.3 & 114.3 \\
\hline & $\begin{array}{l}\text { outside the disaster } \\
\text { zone (control) }\end{array}$ & Atasu & 36.7 & 25.8 & 0.0 & 9.9 & 7.4 & 29.2 & 2.4 & 5.1 & 39.4 \\
\hline \begin{tabular}{|l|} 
The Republic of \\
Kazakhstan
\end{tabular} & - & - & 108.1 & 75.3 & 115.3 & 257.9 & 210.1 & 105.6 & 48.5 & 109.9 & 104.7 \\
\hline
\end{tabular}


We found a shift in morbidity from zero among children between 1 and 2 years of age to $7.4,13.0$ and $13.43 \%$ in the following age groups $(3-6,7-10,11-14)$. The same trend was observed in the villages of Ulytau and Atasu, the latter of which is located outside the disaster zone and is defined as a reference control village. It was noted earlier that the vaccination against $\mathrm{HA}$ was effective in these areas. ${ }^{[6]}$

Thus, the analysis of HA incidence among children in the studied territories showed no connection between the incidence rate and the ecological status of the territory. At the same time, if we consider the relationship between HA incidence and the environmental contamination with HAV-Ag in different regions within same province, a certain connection is revealed. The region rank positions for the environmental HAV-Ag contamination and the HA incidence in the different territories of Kazakhstan are shown in Table 2. As can be seen, in regions of the same area (oblast), there is an identity or similarity in the rank positions according to the environmental HAV-Ag contamination and the HA incidence. This fact is seen most clearly in the regions of Kyzylorda oblast. So, in the Aral region, the rank positions were close (1 and 2). Similar proximity of these ranks was noted in Kazalinsk region (4 and 5), and these positions were the same (3 and 3) in Shiel region. An evident discrepancy was noted in the Zhalagash region (1 and 5). In Aktobe and Karaganda oblasts, the rank positions for the environmental HAV-Ag contamination and the HA incidence fully coincided. These data suggest the presence of a causal link between the environmental HAV-Ag contamination and the HA incidence.[12] This relationship is leveled by vaccination, making it more difficult to analyze in Kazakhstan, where vaccination of children against HA has been conducted from 2004 to 2005 . $^{[11,13,14]}$

Table 2.

The region rank positions for the environmental HAV-Ag contamination and the $\mathrm{HA}$ incidence

\begin{tabular}{|c|c|c|c|c|c|}
\hline Oblast & $\begin{array}{c}\text { Ecological } \\
\text { status }\end{array}$ & Region & $\begin{array}{c}\text { Contami- } \\
\text { nation \& } \\
\text { a rank } \\
\text { position } \\
\% \text {; (№) }\end{array}$ & \begin{tabular}{|c|} 
Incidence \\
rate \& \\
a rank \\
position \\
$0 \%$ \\
$0000 ;(№)$
\end{tabular} & Ranks \\
\hline \multirow{5}{*}{$\begin{array}{l}\text { Kyzylorda } \\
\text { oblast }\end{array}$} & \multirow{2}{*}{$\begin{array}{l}\text { ecological } \\
\text { catastrophe }\end{array}$} & Aralsk & $1.3 ;(1)$ & $185.3 ;(2)$ & $1-2$ \\
\hline & & Kazalinsk & $0.52 ;(4)$ & $86.3 ;(5)$ & $4-5$ \\
\hline & \multirow{3}{*}{ ecological crisis } & Karmakchy & $0.9 ;(2)$ & $101.8 ;(4)$ & $2-4$ \\
\hline & & Zhalagash & $0.5 ;(5)$ & $418.3 ;(1)$ & $5-1$ \\
\hline & & Shieli & $0.6 ;(3)$ & $151.6 ;(3)$ & $3-3$ \\
\hline \multirow{2}{*}{$\begin{array}{l}\text { Aktobe } \\
\text { oblast }\end{array}$} & $\begin{array}{l}\text { ecological } \\
\text { catastrophe }\end{array}$ & Shalhar & $0.3 ;(1)$ & $14.2 ;(1)$ & $1-1$ \\
\hline & ecological crisis & Irgiz & $0.2 ;(2)$ & $11.3 ;(2)$ & $2-2$ \\
\hline $\begin{array}{l}\text { South } \\
\text { Kazakhstan } \\
\text { oblast }\end{array}$ & ecological crisis & Aris & 1.2 & 334.7 & \\
\hline \multirow{2}{*}{$\begin{array}{l}\text { Karaganda } \\
\text { oblast }\end{array}$} & ecological crisis & Ulytau & $0.4 ;(1)$ & $77.9 ;(1)$ & $1-1$ \\
\hline & control zone & Atasu & $0.3 ;(2)$ & $36.7 ;(2)$ & $2-2$ \\
\hline
\end{tabular}

Thus, in the studied regions of Kazakhstan, the average annual incidence rates for HA vary from $11.3 \%$ in Irgiz region of Aktobe oblast to $418.3 \%$ in the Zhalagash region of Kyzylorda oblast. The degree of the environmental HAV-
$\mathrm{Ag}$ contamination varies from $0.2 \%$ to $1.3 \%$. Almost full similarity or the proximity of rank positions among regions for HAV-Ag contamination and morbidity shows a link between these parameters. However, we did not find an association between the degree of HAV-Ag contamination/HA and the severity of the environmental disaster. Thus, the strategic vaccination of children in areas of high endemicity is the most effective way to control HAV, or possibly to eliminate it.

\section{References}

1. WHO. The Global Prevalence of Hepatitis A Virus Infection and Susceptibility: A Systematic Review. Available from: whqlibdoc.who.int/hq/2010/WHO IVB 10.01 eng.pdf. 2. Nelson KE. Global changes in the epidemiology of hepatitis A virus infections. Clin Infect Dis. 2006;42(8):1151-2. 3. WHO position paper on hepatitis A vaccines - June 2012. Wkly Epidemiol Rec. 2012 Jul 13;87(28/29):261-76.

4. Hepatitis A [WHO 2016]. Fact sheet, Updated July 2016 http://www.who.int/mediacentre/factsheets/fs328/en/

5. Franco E, Meleleo C, Serino L, Sorbara D, Zaratti L. Hepatitis A: Epidemiology and prevention in developing countries. World J Hepatol. 2012;4(3):68-73.

6. Shuratov IKh, Omarova MN, Kuatbaeva AM, et al. An analysis of the epidemiology of hepatitis A in Kazakhstan for 2005-2009 and measures for its improvement. Hygiene, Epidemiology and Immunology. 2010;4:53-6. [in Russian].

7. Dzhumagalieva AB, Shuratov IKh, Omarova MN, et al. Characteristics of the population incidence of viral hepatitis A in some urban areas of the Republic. Proceedings of the 8 th International scientific-practical conference «Scientific achievements on the turn of the millennium. Prague, 2012;24:27-32.

8. Resolution of the Supreme Council of RK of 18.01.1990 «On some measures to a radical transformation of the living conditions of the Aral Sea region population.»

9. Mikhailov MI, Shakhgildyan IV, Onishchenko GG. Enteral viral hepatitis (etiology, epidemiology, diagnosis, prevention). M: FGOU VUNZ Rosszdrava, 2007:77-137.

10. Dzhumagalieva AB, Shuratov IKh, Omarova MN, et al. Characteristics of the hepatitis A incidence in some urban areas of Kazakhstan. Proceedings of the $8^{\text {th }}$ Scientific Conference "Perspectives of Science and Technology". M.: Meditsina, 2012;24:39-49. [in Russian].

11. Omarova MN, Dzhumagalieva AB, Shuratov IKh. Changes in the epidemiological characteristics of hepatitis A as an indicator of the effectiveness of vaccination. Proceedings of the $18^{\text {th }}$ International conference "Family Health — the 21 Century". Israel, 2014:113.

12. Omarova MN, Orakbay LZh, Shuratov IKh, Saparbekov $\mathrm{MH}$. Biological factors affecting the health of the population in urban areas. Proceedings of the 14th International Conference "Family Health — the 21 Century". Rimini (Italy),2010:337-8. 13. Shuratov IKh, Omarova MN, Kuatbaeva AM. Analysis of the effectiveness of vaccination against vaccine-preventable diseases in Kazakhstan. Proceedings of the 4th All-Russian Conference "Medical and physiological problems of human ecology". Ulyanovsk, 2014:308-9. [in Russian].

14. Omarova M, Orakbay L, Shuratov I, Dzhumagalieva A, Zharkinov E, Kenzhebaeva A, Tyan A. Acute intestine infection and hepatitis A disease risk analysis in urban areas of the Republic of Kazakhstan. Med Health Sci J. 2012;13:33-40. 